\title{
Jenis-jenis Burung di Daerah Pasui Kecamatan Buntu Batu Kabupaten Enrekang
}

\author{
Hasyimuddin'1, St. Aisyah Sijid², Andika Saputra ${ }^{3}$ \\ Jurusan Biologi, Fakultas Sains dan Teknologi, UIN Alauddin Makassar \\ Email: 1hasyimuddin@uin-alauddin.ac.id
}

\begin{abstract}
Birds are living organisms classified into the Kingdom Animalia, phylum Aves and including organisms that possess similar characteristics with body cover in the form of feathers and can fly. The aim of this study was to determine the diversity of bird species found in Pasui Village, Buntu Batu District, Enrekang Regency. This research was conducted at Pasui watershed. Birdwatching is done by cruising method at three different stations. The results of this study found 14 bird species classified into 5 orders, 11 families and 13 genera. The bird species obtained are Haliastur indus, Collocalia esculenta, Egretta alba, Chalcophaps indica longirostris, Streptopelia chinensin, Corvus enca, Dicaeum aureolimbatum, Eruthrura hyperythra, Lonchura Malacca, Lonchura punctulata, Passer montanus, Pycnonotus aurigaster, Acridontheres javanicus, Zosterops pelpepbrosus.
\end{abstract}

Keywords: Bird, Watershed, Pasui Village

\section{Pendahuluan}

Kawasan Wallacea terletak diantara kawasan Oriental dan Australia yang terdiri atas ribuan pulau. Karena letaknya berada diantara dua kawasan, sehingga Wallacea menjadi rumah bagi elemen fauna campuran Oriental dan Australia yang mengagumkan. Selain itu, kondisi kawasan Wallacea yang terisolasi di lautan menjadi arena evolusi jenis burung endemik yang jumlahnya sangat banyak (Coates and Bishop, 2000).

Sebagai salah satu wilayah di Kawasan Wallacea, Pulau Sulawesi menyimpan berjuta misteri berkaitan dengan potensi sumber daya alamnya, alam Sulawesi menjadi perhatian konservasionis dunia karena menjadi tempat hidup berbagai satwa endemik yang bernilai global. Menariknya bahwa pulau Sulawesi tidak memiliki keanekaragaman burung yang tinggi sebagaimana pulau lain di wilayah barat Indonesia namun endemisitas terhadap jenis ini justru lebih tinggi. Tercatat sekitar 96 jenis burung endemik di wilayah Sulawesi yang tersebar dari Selatan, Tenggara, Tengah hingga ke bagian Utara yang lebih kaya akan pulaupulau kecil (Arini dkk, 2011).

Inventarisasi jenis burung yang ada pada suatu wilayah atau habitat menjadi salah satu acuan dalam pengelolaan sumber daya hayati. Burung sangatlah berperan dalam dinamika ekosistem serta penghubung hidup dari ekosistem yang ada di alam, burung mengendalikan populasi serangga, membantu penyerbukan dan penyebaran biji (Haryoko, 2011).

Pasui merupakan salah satu daerah di Kabupaten Enrekang Sulawesi Selatan. Wilayah daerah ini merupakan dataran pegunungan dan berbukit serta dihiasi beberapa vegetasi yang masih alami. Wilayah ini juga memiliki daerah aliran sungai yang subur dan bisa menyediakan makanan sehingga memungkinkan dijadikan rumah bagi burung untuk berkembang biak pada daerah tersebut (BPS Enrekang, 2017).

Kurangnya perhatian dari masyarakat sekitar dan minimnya informasi mengenai keragaman jenis burung pada daerah Pasui menjadi dasar dalam melakukan penelitian ini. 
Penelitian ini bertujuan untuk mengetahui ragam jenis burung yang terdapat di Desa Pasui Kecamatan Buntu Batu Kabupaten Enrekang.

\section{Metode}

Penelitian ini telah dilaksanakan pada musim penghujan di daerah aliran sungai Pasui. Pengamatan burung dilakukan dengan metode jelajah pada tiga stasiun berbeda.

Pengamatan dilakukan menggunakan teropong dengan mengamati burung yang berada diaerah aliran sungai dan melakukan identifikasi langsung dengan mencocokkan dengan buku identifikasi. Bila memungkinkan dilakukan pengambilan gambar burung dengan menggunakan kamera DSLR. Gambar yang didapatkan kemudian diidentifikasi lebih lanjut dengan menggunakan buku acuan Buku burungburung Sumatera, Jawa, Bali dan Kalimantan (MacKinnon, Phillipps dan Balen, 2010), A Guide To The Birds of Wallacea : Sulawesi, The Moluccas and Lesser Sunda Island, Indonesia (Coates, 2000) dan Keanekaragaman Avifauna Beberapa Kawasan Konservasi Propinsi Sulawesi Utara Dan Gorontalo (Arini dkk, 2011).

Pengamatan dilakukan pada setiap stasiun masing masing selama 3 hari pada pagi hari (pukul 06.00-09.00) kemudian dilanjutkan pada sore hari (15.00-18.00) yang merupakan waktu burung sedang aktif beraktifitas (Putri, 2015).

\section{Hasil dan Pembahasan}

Berdasarkan penelitian yang telah dilakukan di Daerah Aliran Sungai Pasui dengan menggunakan teropong didapatkan 14 spesies burung yang termasuk ke dalam 11 famili dengan jumlah total 109 individu. Jenis-jenis burung yang didapatkan disajikan pada Tabel 1 . Dari Tabel tersebut dapat dilihat, Ordo yang didapatkan terdiri dari lima Ordo yaitu, Accipriformes, Apodiformes, Pelecaniformes, Columbiformes, Passeriformes. Dari kelima ordo tersebut, ordo Passeriformes memiliki jumlah spesis terbanyak yaitu sembilan spesies sedangkan ordo Acciptiformes, Apodiformes dan
Pelecaniformes masing-masing hanya terdapat satu spesis yang berhasil didata.

Spesis yang paling banyak ditemukan dari ordo Passeriformes yaitu dari famili Estrildidae dengan tiga spesies yaitu Eruthrura hyperythra (Bondol hijau dada merah), Lonchura Malacca (Bondol rawa), dan Lonchura punctulata (Bondol peking). Sedangkan individu yang paling banyak dijumpai pada famili ini yaitu Lonchura Malacca (Bondol rawa) sebanyak 29 individu. Banyaknya burung jenis bondol ditemukan pada daerah ini karena sebagian besar wilayah DAS Pasui merupakan area persawahan dengan tanaman padi sebagai tanaman utama sehingga dapat menyediakan makan bagi burung yang merupakan makanan utama bagi burung pada famili ini. Jenis burung bondol merupakan jenis burung pemakan biji tanaman rumput-rumputan, juga memanfaatkan tumbuhan rumput-rumputan sebagai bahan untuk membuat sarangnya (Ciptono dkk, 2017).

Dari 3 stasiun yang diamati, stasiun 2 paling banyak dijumpai jenis burung yaitu 8 jenis. Stasiun 2 memiliki tipe vegetasi yang bervariasi dengan perpaduan lahan persawahan sebagai penyedia makanan bagi burung dan juga disekitarnya terdapat vegetasi alami seperti pohon yang dapat dijadikan tempat istirahat dan membuat sarang bagi burung tersebut. Sedangkan pada stasiun 3 paling sedikit dijumpai jenis burung, hal ini dikarenakan vegetasi pada stasiun 3 didominiasi tumbuhan perkebunan bukan penghasil buah sehingga ketersediaan sumber pakan bagi burung terbatas pada stasiun ini. Hamzati (2013) menyatakan bahwa struktur vegetasi merupakan salah satu kunci kekayaan jenis burung pada tingkat lokal.

\section{Simpulan}

Kesimpulan dari penelitian ini adalah tedapat 14 spesis burung yang tergolong ke dalam 5 ordo, 11 famili dan 13 genus. Spesis burung yang didapatkan adalah Haliastur indus (Elang Bondol), Collocalia esculenta (Burung Walet Sapi), Egretta alba (Kuntul Besar), Chalcophaps indica longirostris (Merpati sayap hijau), Streptopelia chinensin 
Hasyimuddin, St. Aisyah Sijid, Andika Saputra

Tabel 1. Jenis-jenis Burung di Daerah Aliran Sungai Pasui Kec. Buntu Batu Kab. Enrekang

\begin{tabular}{|c|c|c|c|c|c|c|c|c|c|}
\hline \multirow{2}{*}{ No } & \multirow{2}{*}{ Ordo } & \multirow{2}{*}{ Famili } & \multirow{2}{*}{ Genus } & \multirow{2}{*}{ Spesies } & \multirow{2}{*}{ Jenis } & \multicolumn{3}{|c|}{ Stasiun } & \multirow[t]{2}{*}{ Tota } \\
\hline & & & & & & 1 & 2 & 3 & \\
\hline 1 & Acciptriformes & Acciptridae & Haliastur & Haliastur indus & Elang Bondol & - & 1 & 2 & 3 \\
\hline 2 & Apodiformes & Apodidae & Collocalia & Collocalia esculenta & Burung Walet Sapi & 7 & - & 5 & 12 \\
\hline 3 & Pelecaniformes & Ardeidae & Egretta & Egretta alba & Kuntul Besar & - & 5 & - & 5 \\
\hline \multirow[t]{2}{*}{4} & Columbiformes & Columbidae & Chalcophaps & Chalcophaps indica longirostris & Merpati sayap hijau & 1 & - & - & 1 \\
\hline & & & Streptopelia & Streptopelia chinensin & Tekukur biasa & - & - & 2 & 2 \\
\hline \multirow[t]{9}{*}{5} & Passeriformes & Corvidae & Corvus & Corvus enca & Gagak hutan & - & - & 1 & 1 \\
\hline & & Dicaeidea & Dicaeum & Dicaeum aureolimbatum & Cabai panggul kuning & - & 5 & - & 5 \\
\hline & & & Lonchura & Lonchura malacca & Bondol rawa & 20 & 9 & - & 29 \\
\hline & & & & Lonchura punctulata & Bondol peking & 8 & 7 & - & 15 \\
\hline & & Passiredae & Passer & Passer montanus & Burung Gereja & 17 & - & - & 17 \\
\hline & & Pycnonotidae & Pycnonotus & Pycnonotus aurigaster & Cucak kutilang & - & 3 & 7 & 10 \\
\hline & & Sturnidae & Acridontheres & Acridontheres javanicus & Jalak kerbau & - & 1 & - & 1 \\
\hline & & Zosteropidae & Zosterops & Zosterops pelpepbrosus & Kacamata biasa & 4 & - & - & 4 \\
\hline & & & & Total & & 57 & 35 & 17 & 109 \\
\hline
\end{tabular}

(Tekukur biasa), Corvus enca (Gagak hutan), Dicaeum aureolimbatum (Cabai panggul kuning), Eruthrura hyperythra (Bondol hijau dada merah), Lonchura Malacca (Bondol rawa), Lonchura punctulata (Bondol peking), Passer montanus (Burung Gereja), Pycnonotus aurigaster (Cucak kutilang), Acridontheres javanicus (Jalak kerbau), Zosterops pelpepbrosus (Kacamata biasa).

\section{Daftar Pustaka}

Arini D. I. H, Shabri S., Kafiar Y., Tabba S., Kama H. 2011. Keanekaragaman Avifauna Beberapa Kawasan Konservasi Propinsi Sulawesi Utara Dan Gorontalo. Manado: Balai Penelitian Kehutanan Manado Badan Penelitian dan Pengembangan Kehutanan Kementrian Kehutanan.
Badan Pusat Statistik Kabupaten Enrekang. 2017. Kecamatan Buntu Batu Dalam Angka 2017. Enrekang: Badan Pusat Statistik Kabupaten Enrekang.

Ciptono, A. T. dan Handziko R. C. 2017. Pengaruh Faktor Lingkungan Klimatik dan Kondisi Habitat Terhadap Perilaku Bersarang Burung Bondol Haji (Loncura maja). Prosiding Seminar Nasional Pendidikan Biologi dan Biologi Jurusan Pendidikan Biologi, Fakultas MIPA Universitas Negeri Yogyakarta. 27-38.

Coates, B. J. and Bishop, K. D. 2000. A Guide To The Birds Of Wallacea : Sulawesi, The Moluccas and Lesser Sunda Island, Indonesia. Australia: Dove Publications.

Hamzati, N. S. dan Aunurohim. 2013. Keanekaragaman Burung di Beberapa Tipe Habitat di Bentang Alam Mbeliling Bagian Barat, Flores. Jurnal Sains dan Seni Pomits. 2(2): 121-126. 
Haryoko, T. 2011. Keanekaragaman jenis burung di Bunguran Utara, Pulau Bunguran, Kabupaten Natuna. Zoo Indonesia, 20(2): 17-25.

MacKinnon, J. K., Phillip, K., dan Balen, B. V. 2010. Seri Panduan Lapangan BurungBurung di Sumatera, Jawa, Bali dan Kalimantan. Bogor: Pusat Penelitian dan Pengembangan Biologi LIPI.

Putri, A. S. L. P., Indra. 2015. Pengaruh kekayaan jenis tunbuhan sumber pakan terhadap keanekaragaman burung herbivora di Taman Nasional Bantimurung Bulusaraung Sulawesi Selatan. Pros Semnas Masy Biodev Indon. 1(3): 607-614. 